NBER WORKING PAPER SERIES

\title{
THE STOCK MARKET AND INVESTMENT: EVIDENCE FROM FDI FLOWS
}

\author{
Malcolm Baker \\ C. Fritz Foley \\ Jeffrey Wurgler \\ Working Paper 10559 \\ http://www.nber.org/papers/w10559
NATIONAL BUREAU OF ECONOMIC RESEARCH 1050 Massachusetts Avenue
Cambridge, MA 02138
June 2004

\begin{abstract}
We thank Yakov Amihud, Kobi Bodoukh, Kathryn Dewenter, Rocky Higgins, Jim Hines, Jack Porter, Andrei Shleifer, Jeremy Stein, Paul Wachtel, Bernie Yeung, and seminar participants at Harvard, NYU, UCLA, and the University of Washington for helpful comments. We also thank Ryan Taliaferro and Maggie Zhou for excellent research assistance. Baker thanks the Division of Research of the Harvard Business School and Foley thanks the NTT Program of Asian Finance and Economics at the University of Michigan Business School for financial support. The views expressed herein are those of the author(s) and not necessarily those of the National Bureau of Economic Research.
\end{abstract}

(C2004 by Malcolm Baker, C. Fritz Foley, and Jeffrey Wurgler. All rights reserved. Short sections of text, not to exceed two paragraphs, may be quoted without explicit permission provided that full credit, including (C) notice, is given to the source. 
The Stock Market and Investment: Evidence from FDI Flows

Malcolm Baker, C. Fritz Foley, and Jeffrey Wurgler

NBER Working Paper No. 10559

June 2004

JEL No. G31

\title{
$\underline{\text { ABSTRACT }}$
}

Foreign direct investment offers a rich laboratory in which to study the broader economic effects of securities market mispricing. We outline and test two mispricing-based theories of FDI. The "cheap assets" or fire-sale theory views FDI inflows as the purchase of undervalued host country assets, while the "cheap capital" theory views FDI outflows as a natural use of the relatively lowcost capital available to overvalued firms in the source country. The empirical results support the cheap capital view: FDI flows are unrelated to host country stock market valuations, as measured by the aggregate market-to-book-value ratio, but are strongly positively related to source country valuations and negatively related to future source country stock returns. The latter effects are most pronounced in the presence of capital account restrictions, suggesting that such restrictions limit cross-country arbitrage and thereby increase the potential for mispricing-driven FDI.

\author{
Malcolm Baker \\ Harvard Business School \\ Morgan Hall 361 \\ Boston, MA 02163 \\ and NBER \\ mbaker@hbs.edu \\ C. Fritz Foley \\ University of Michigan \\ ffoley@umich.edu \\ Jeffrey Wurgler \\ Stern School of Business, Suite 9-190 \\ New York University \\ 44 West 4th Street \\ New York, NY 10012 \\ and NBER \\ jwurgler@stern.nyu.edu
}




\section{Introduction}

On occasion, prices in capital markets deviate from fundamental values by significant amounts. ${ }^{1}$ How does capital market mispricing affect corporate investment patterns? A considerable body of theoretical work has considered this question. Most of it predicts that real investment will be positively correlated with mispricing. For instance, Keynes (1936) highlights the effect of stock market misvaluation on the cost of equity, while Bernanke and Gertler (1995) and Bernanke, Gertler, and Gilchrist (2000) point out that equity mispricing can, through its impact on perceived collateral values, also affect the cost of debt. In a related vein, Stein (1996) and Baker, Stein, and Wurgler (2003) discuss how equity undervaluation constrains real investment. More recently, Shleifer and Vishny (2003) consider how mispricing affects merger and acquisition activity, predicting that overvalued firms tend to be acquirers and noting that undervalued firms make especially attractive targets.

The empirical literature, in contrast, is much less settled. For example, Morck, Shleifer, and Vishny (1990) and Blanchard, Rhee, and Summers (1993) find little evidence that mispricing affects investment, while Chirinko and Schaller (2001, 2004) and Baker et al. (2003) argue that it may have important effects. ${ }^{2}$ Others find that stock prices are strong determinants of equity and debt issuance, and that firms that raise external finance experience unusually low stock returns, on average, following the issue, suggesting that they were successful in timing their issues to periods when capital was cheap. But once again, others dispute the interpretation

\footnotetext{
${ }^{1}$ For surveys of the vast literature on capital market inefficiencies, including discussions of the reasons why mispricings are not easily arbitraged away, see Shleifer (2000) and Barberis and Thaler (2002).

${ }^{2}$ See also Fisher and Merton (1984), Barro (1990), Polk and Sapienza (2003), and Gilchrist, Himmelberg, and Huberman (2003).
} 
of these results. ${ }^{3}$ A fair summary is that empirical studies on whether and how mispricing affects corporate investment patterns leave open many questions.

In this paper, we examine whether and how stock market mispricing affects foreign direct investment (FDI). Prior studies have focused on other determinants of FDI. For instance, theories of the multinational enterprise grounded in the trade literature stress the roles of host country market size, production scale economies, factor endowments, trade and investment barriers, and tax rates. ${ }^{4}$ Froot and Stein (1991) and Klein, Peek and Rosengren (2002), among others, consider the interaction of exchange rate shocks and capital market imperfections. This work has yielded many important insights about the complex nature of foreign direct investment. It has tended to assume, however, that international capital markets are integrated and informationally efficient, which runs contrary to accumulating evidence. At the same time, FDI offers a potentially quite rich setting in which to look for broader effects of mispricing. Among other advantages, it allows the researcher to separately study the impact of host and source country valuations. This is useful because host country valuations contain relatively more information about investors’ perceptions of the marginal profitability of FDI, while source country valuations say more about a foreign investor's cost of capital. Within-country investment-Q equations do not allow for any analogous separation, limiting what can be learned.

\footnotetext{
${ }^{3}$ Studies that connect valuations to equity issuance include Marsh (1982), Asquith and Mullins (1986), Loughran, Ritter, and Rydqvist (1994), Jung, Kim, and Stulz (1996), Pagano, Panetta, and Zingales (1998), and Graham and Harvey (2001). Stigler (1964), Loughran and Ritter (1995), and Baker and Wurgler (2000), among others, find that equity issuers have abnormally low equity returns in the years following the issue, but Brav and Gompers (1997) and Fama (1998) challenge the interpretation of some of these results. Speiss and Affleck-Graves (1999) find that speculative-grade debt issuers experience low subsequent stock returns, and Richardson and Sloan (2003) find that raising external equity or debt is associated with low subsequent returns. Dong, Hirshleifer, Richardson, and Teoh (2003) and Verter (2003) find support for the mispricing-driven view of mergers in US data.

${ }^{4}$ Models of horizontal investment, such as Markusen (1984), predict more investment in larger markets where gains from avoiding trade costs outweigh the costs of building additional capacity. Models of vertical investment, such as Helpman (1984), describe the incentive to locate production to take advantage of factor cost differences. Empirical evidence on these channels include Brainard (1997), Carr, Markusen, and Maskus (2001), Blonigen, Davies, and Head (2003), and Yeaple (2003). Gordon and Hines (forthcoming) survey the literature on the effect of host country tax rates on FDI.
} 
To better motivate how mispricing could affect FDI, let us start with an example of such mispricing. Froot and Dabora (1999) study the share prices of Royal Dutch, which trades mainly in the US, and Shell Transport, which trades mainly in the UK. Royal Dutch and Shell pay dividends in a 60:40 ratio in accord with a longstanding merger agreement. Hence, if capital markets were efficient and integrated, the relative price would be fixed at 60:40. Yet Froot and Dabora find that the actual ratio varies between 36:40 and 66:40 in their sample. Moreover, they find that the relative price of Royal Dutch increases when the US stock market increases relative to the UK market, suggesting broad, country-level investor demand pressures. While Royal Dutch-Shell is but one case, it involves a very large multinational whose share prices are set on the world's best-functioning capital markets, and other such "Siamese twin" shares exhibit similar deviations from theoretical parity. ${ }^{5}$ Accumulated evidence of this sort suggests the hypothesis that mispricings of corporate assets across international markets, while difficult to cleanly document except in rather special cases, could be widespread enough to have detectable effects on international capital flows.

Specifically, we consider two channels through which mispricing could affect FDI. We call the first the "cheap assets" channel. In this channel, FDI inflows represent the purchase of undervalued host country assets—or, to be precise, the purchase of host assets at less than their integrated-and-efficient-world-markets benchmark price. Undervaluation could result from low investor sentiment for host country assets, or a liquidity crisis that causes liquidity-constrained firms to be available to unconstrained foreign acquirers at "fire sale" prices. The latter story is

\footnotetext{
${ }^{5}$ Rosenthal and Young (1990), Froot and Dabora (1999), and de Jong, Rosenthal, and van Dijk (2003) discuss other cases of "Siamese twin" shares whose relative price behavior seems best explained by some form of relative market mispricing. Studies of country closed-end funds by Hardouvelis, La Porta, and Wizman (1994) and Bodurtha, Kim, and Lee (1995) offer another clean setting in which the valuation of a set of cash flows appears to depend on where it trades. Bekaert (1995), Bekaert and Harvey (1995), and Henry (2000) find evidence of stock market segmentation in broader samples of countries and firms.
} 
developed in Froot and Stein (1991), Shleifer and Vishny (1992), Krugman (1998) and Aguiar and Gopinath (2003). Empirical evidence on this channel is limited to Aguiar and Gopinath (2003), who find that cross-border M\&A into five Asian countries increased during the late1990s crisis, with foreign acquirers concentrating on liquidity-constrained targets.

The second channel is the "cheap capital" channel. Here, FDI outflows represent a natural use of the low-cost capital available to overvalued firms in the source country. To the extent that much FDI is cross-border M\&A, such a channel can arise as an application of the Shleifer and Vishny (2003) model of mispricing-driven acquisitions to a cross-border setting. Shleifer and Vishny point out that managers of an overvalued acquirer may know that their overpricing will end eventually, but in the meantime they can benefit their ongoing investors, at the cost of new ones, by purchasing less-overvalued assets with new capital. For firms that are overvalued because of a domestic bubble, natural candidate investments would include targets abroad that are not overvalued or zero-net-present value greenfield investment. Moreover, through its effect on perceived collateral values, overpriced equity also can reduce the cost of debt, and thus can stimulate cash-financed FDI. ${ }^{6}$ In one respect, the cheap capital channel seems more plausible than the cheap assets channel: It asks a manager to identify misvaluation only of his own firm, as

\footnotetext{
${ }^{6}$ In Baker et al. (2003), overvalued equity relaxes a binding leverage constraint, creating debt capacity, but debt is correctly priced. In practice, mispriced equity can also affect the cost of debt. For instance, in a manner like the balance sheet channel in Bernanke and Gertler (1995), credit-scoring models used widely by financial institutions, such as those developed by Moody's KMV, use a firm's share price as an input to compute the probability that it will default. Overpriced shares thus can lead to an underestimate of credit risk and and an abnormally low cost of debt (and vice-versa). Typical extensions of such models, such as KMV's Private Firm Model, estimate credit risk for private firms using stock market valuations for comparable public firms. The widespread use of such models suggests how a domestic stock market bubble can affect the cost of capital for even nontraded firms. The balance sheet channel, combined with the parent's implicit guarantee of its affiliates' debt [Caves (1999, p. 139)], also suggests how mispricing in the source country capital market affects an affiliate's cost of capital even when that capital is raised locally.
} 
opposed to that of a target asset that may be thousands of miles away. ${ }^{7}$ We appear to be the first to outline and test a cheap capital approach to FDI.

Overall, our empirical results tell a very consistent story: The cheap assets channel is not important, at least as a general determinant of FDI, and the cheap capital channel appears to be quite important. We make use of three FDI data sets. The main one is the BEA panel of FDI flows between the US and nineteen other countries, from 1974 through 2001. We also examine data on cross-border mergers and acquisitions involving US firms, and a large bilateral panel of FDI flows among twenty countries. We start with simple regressions that show that FDI outflows are strongly positively related to the average market-equity-value-to-book-equity-value ratio of publicly traded firms in the source country, consistent with a cheap capital channel. In contrast, FDI inflows are not related to the market-to-book ratios of the host country, inconsistent with fire sales. These results are evident in all of our data sets and are robust to various specification choices. Put simply, high source country stock market valuations push out FDI, but low host country valuations do little to pull it in. Indeed, the push effect of valuations is considerably stronger than that of any of several control variables we include.

Of course, stock market valuations capture not only mispricing but also many other fundamental drivers of FDI. An important part of our analysis is to develop and implement a fairly general methodology that allows us to confirm, to the extent possible, that FDI outflows are specifically connected to the component of source country market valuations that reflect

\footnotetext{
${ }^{7}$ In addition to information, multinationals have certain other advantages over portfolio investors in conducting cross-market arbitrage. For example, consider a hedge fund manager who sells short to exploit a perceived overpricing of his country's stock market. If the mispricing gets worse before it corrects, he may have to close the position at a loss due to margin requirements or agency relationships that shorten his horizon [Shleifer (2000), ch. 2 and ch. 4]. Brunnermeier and Nagel (2004) find that US hedge funds generally ride the Internet bubble rather than trade against it. The manager of an overvalued multinational, on the other hand, is in a better position: If she raises external finance to acquire overseas assets, and her firm's shares then appreciate further, her shareholders are unlikely to be upset. Stein (2004) develops this argument. In sum, we do not suggest that FDI is the sole form of international capital market arbitrage, but in contrast to Hymer (1960) we do find it a priori quite reasonable that it may be one such form.
} 
mispricing. Three results serve to establish such a connection. First, we apply the logic that mispricings tend to correct over time, and use ex post stock market returns to instrument for the component of market-to-book that reflects ex ante mispricing. We find that FDI outflows are strongly related to this component. Second, we exploit the observation that capital controls limit cross-market arbitrage and thus, other things equal, increase the likelihood that an extreme market-to-book ratio reflects mispricing. (Exogenous variation of this sort, unavailable to withincountry studies, is another crucial advantage to using FDI to study the economic effects of mispricing.) We find that source country valuations indeed have stronger effects in the presence of capital controls. Third, we combine the two approaches. We find that the component of source country market-to-book associated with mispricing has its strongest effect in country-years in which capital accounts are less open.

To summarize, the results provide the first evidence that stock market valuations and mispricing may play an important role in FDI patterns, and in a manner consistent with a cheap capital but not a cheap assets channel. However, a caveat is that although our data sets include the vast majority of FDI flows, they focus on fairly developed countries. Thus, the results do not necessarily conflict with Aguiar and Gopinath’s (2003) evidence of fire sales in a small set of developing countries during a financial crisis. Our more positive and important conclusion is that a novel "cheap capital” view of FDI receives consistent support. This adds a new dimension to the FDI literature and also sheds indirect light on why, within countries, investment and merger activity are positively correlated with stock prices.

The rest of the paper proceeds in three sections. Section II describes our econometric methodology and our data. Section III contains the empirical results. Section IV concludes. 


\section{Methodology and data}

\section{A. Methodology}

The two main hypotheses are that FDI is higher when the capital in the source country is cheaper (i.e., when the source country stock market is overvalued) and when the assets in the host country are cheaper (i.e., when the host country stock market is undervalued). The key econometric challenge is to separate the effect of stock market misvaluation from the effects of other influences on FDI, in particular those that are also reflected in stock market valuations. In this subsection, we develop our methodological approach in terms of the effect of source country valuations. The analysis for host country valuations is almost identical. Suppose that the FDI flow from source country $i$ to host country $j$ is given by

$$
F D I_{i j t}=a+b \delta_{i t}+c_{S} \phi_{i t}+c_{H} \phi_{j t}+\varepsilon_{1 i j t},
$$

where $\delta$ is the degree of overvaluation in country $i$ at time $t$ and $\phi_{k}$ measures fundamentals in country $k$. Fundamentals are a potentially long vector of country characteristics, which in principle would include the level of human capital, legal or technological development, profitable investment opportunities, and other fundamental (i.e., non-mispricing) determinants of FDI, multiplied by a set of loadings. We are interested in whether $b$ is greater than zero.

The first approach is to run regressions using the country-level market-to-book-value ratio as a proxy for $\delta$. If book value serves as a rough measure of fundamentals, a high marketto-book suggests that the country's stock market may be overvalued. ${ }^{8}$ Market-to-book is inversely related to future equity returns in the cross-section of US stocks (Basu (1983), Fama and French (1992)) and international stocks (Fama and French (1998)). Also, the aggregate US

\footnotetext{
${ }^{8} \mathrm{~A}$ country-level price-earnings or price-dividend ratio could also be used as a proxy for misvaluation. Scaling by book equity is preferable since it ensures that the denominator is positive and it reduces the influence of transient fluctuations in profits or payouts.
} 
market-to-book ratio is inversely related to subsequent market returns (Kothari and Shanken (1997), Pontiff and Schall (1998)). These results are consistent with the idea that extreme values of market-to-book represent, in part, misvaluations that subsequently correct. Extreme values of market-to-book are directly connected to extreme investor expectations by La Porta (1996), La Porta, Lakonishok, Shleifer, and Vishny (1997), and Frankel and Lee (1998). With this literature as motivation, we start with regressions of the type

$$
F D I_{i j t}=\hat{a}+\hat{b}_{1} \frac{M}{B}_{i t}+e_{1 i j t} .
$$

Of course, a positive and significant coefficient does not prove that $b>0$, since

$$
\frac{M}{B}_{i t}=d+\delta_{i t}+\phi_{i t},
$$

where the coefficients on $\delta$ and $\phi$ are normalized to be one. (Also to ease the exposition, we assume that there is no measurement error in the market-to-book ratio.) In other words, while the market-to-book ratio may be a good proxy for $\delta$, it is also a good proxy for the other omitted country characteristics that influence FDI. For example, some theories of FDI link investment to host country GDP, tax rates, and factor endowments, and these fundamentals may be correlated with the stock market. As a result, $b_{1}$ will be a biased estimator of $b$. Some of these effects we can control for directly in eq. (2), but omitted variable bias will inevitably remain.

For example, it is particularly challenging to control for the rational expectations version of the wealth effect in Froot and Stein (1991), further examined in Klein and Rosengren (1994), Dewenter (1995), and Klein, Peek, and Rosengren (2002). According to this theory, FDI patterns are driven by cross-country differences in firms' collateralizable wealth, or financial slack. Favorable shocks to relative wealth, as might result from stock market fluctuations or unhedged 
exchange rate changes, allow firms in the relative-wealth-increasing country to escape borrowing constraints and outbid firms in the relative-wealth-decreasing country for domestic assets.

To address the generic omitted variable bias, we take two approaches. The first is to use the future returns on the source country stock market as a cleaner proxy for mispricing. The idea is that, if the stock market were overvalued at the end of 1990, we would expect lower returns in subsequent years as the mispricing is corrected. Unfortunately, there is no a priori notion of the exact horizon over which to expect correction. Too short a horizon leaves open the possibility that the ex ante mispricing has not yet corrected, while too long a horizon reduces power in a short time series. We use one-year-ahead returns to match the collection period of our FDI data. This is also consistent with the results of Kothari and Shanken (1997) and Pontiff and Schall (1998), who find that aggregate market-to-book forecasts one-year-ahead returns. Putting this in the context of eq. (1), we view returns at $t+1$ as a function of $\delta$ at time $t$,

$$
R_{i t+1}=e+f \delta_{i t}+\varepsilon_{2 i t+1},
$$

where $f<0$, i.e. overvaluation at time $t$ leads to lower average returns in $t+1$. Here, we assume that future returns are not related to fundamentals $\phi$. In other words, we assume that countries with a higher level of human capital, legal or technological development, or growth opportunities do not have systematically lower returns. ${ }^{9}$ Our first approach is then to regress market-to-book on future returns and to use the fitted values from that first stage to explain FDI,

$$
F D I_{i j t}=\hat{a}+\hat{b}_{2} \frac{\hat{M}}{B}{ }_{i t}+e_{2 i j t} .
$$

Because the fitted values are uncorrelated with $\phi$, this gives us an unbiased estimate of $b$.

\footnotetext{
${ }^{9}$ The orthogonality conditions are that the correlations between $\delta$ and $\varepsilon_{2}$, and between $\phi$ and $\varepsilon_{2}$, are zero.
} 
Our second approach addresses a potential shortcoming of the first: that the correlation between $\phi$ and $\varepsilon_{2}$ is not zero. That is, suppose investors are routinely too optimistic when underlying investment opportunities are genuinely good—-the recent US Internet bubble fits this pattern. Under this story, future returns and FDI could be connected without any causality from $\delta$ to FDI. ${ }^{10}$ To address this possibility, our second approach exploits cross-country variation in capital market openness and the omitted variable bias in eq. (2) to put a lower bound on the magnitude of $b$.

To illustrate, we start by substituting eq. (3) into eq. (1) to get a clearer view of the omitted variable bias. Without loss of generality, we can substitute for $\phi$, obtaining

$$
F D I_{i j t}=\left(a-c_{S} d\right)+c_{S} \frac{M}{B}_{i t}+\left(b-c_{S}\right) \delta_{i t}+c_{H} \phi_{j t}+\varepsilon_{1 j i t} .
$$

Hence in the simple regression of FDI on market-to-book in eq. (2), the independent variable is not orthogonal to the residuals. The omitted variable bias takes the form:

$$
\hat{b}_{1}=c_{S}+\left(b-c_{S}\right) \frac{\operatorname{cov}\left(\frac{M}{B}{ }_{i t}, \delta_{i t}\right)}{\operatorname{var}\left(\frac{M}{B} i t\right)},
$$

where the ratio is the fraction of the market-to-book ratio that is explained by mispricing. As is intuitive, when all variation in market-to-book is due to mispricing, the coefficient is an unbiased estimate of $b$, and when mispricing is nonexistent, it is an unbiased estimate of $c_{S}$.

\footnotetext{
${ }^{10}$ Another critique of our first approach is that $\mathrm{M} / \mathrm{B}$ might predict returns because it is capitalizing the "rational" discount rate for assets in that country-lower costs of capital imply higher $\mathrm{M} / \mathrm{B}$ and lower required (expected future) returns. Keep in mind that our null hypothesis is efficient and integrated world capital markets. Under this null, risk premia are set on the world capital market, and variation in valuation ratios such as M/B reflect either variation in rational expectations of corporate cash flows (i.e., fundamental investment opportunities) or in the risk inherent in those cash flows, but not in risk premia, since they are not country-specific under the null. Put differently, while variation in a country's $\mathrm{M} / \mathrm{B}$ could reflect rational variation in the cost of capital of firms traded within that country, this could, under the null, only reflect the relatively low risk of corporate assets in that country. It does not mean that those firms would have any cost advantage in purchasing overseas assets (or, indeed, domestic assets), and hence there is no reason, under the null, for such a component of $\mathrm{M} / \mathrm{B}$ to explain international capital flows. In any case, this critique is addressed by our second approach to omitted variable bias.
} 
In perfectly integrated capital markets, arbitrage will reduce the absolute value of $\delta^{11}$ This suggests using the degree to which the capital market is closed as an indicator of where $\delta$ might appear in the first place. Suppose that capital market closedness perfectly measures the extent (not the direction) of the mispricing problem, i.e. the fraction of country stock valuations not explained by fundamentals. Then we can substitute eq. (7) into eq. (2) and estimate

$$
F D I_{i j t}=\hat{a}+\left(\hat{b}_{3} C A C_{i t}+\hat{c}_{S}\right) \cdot \frac{M}{B}+e_{3 i j t}
$$

where $C A C$ measures the degree to which the capital market in country $i$ is closed at $t$. $b_{3}$ is not a direct estimate of $b$ but of $\left(b-c_{S}\right)$. Thus if $b_{3}$ is greater than zero, we can infer that a unit change in the mispricing component of market-to-book has a greater impact on FDI than a unit change in the fundamentals component.

To reiterate, our second approach to omitted variable bias uses the observation that, all else equal, cross-market mispricing is more likely when cross-market arbitrage is difficult, and takes the presence of capital restrictions as a natural proxy for this difficulty. The cheap capital hypothesis then predicts that FDI and valuations will be especially closely related when the source market is segmented from others. Other theories of FDI that assume efficient and integrated capital markets, including the relative wealth theory of Froot and Stein (1991), do not make this prediction. More generally, if the relationship between FDI and valuations is spurious, there is no reason it should strengthen in the presence of capital controls.

Finally, a fuller version of the model would suggest that the sensitivity of FDI to the component of valuations that reflects mispricing would be higher when capital controls are

\footnotetext{
${ }^{11}$ Of course, even within a single capital market, relative mispricing can appear, as demonstrated by Mitchell, Pulvino, and Stafford (2002) and Lamont and Thaler (2003). But within a single market as well, mispricings are more common and more severe among securities where arbitrage is relatively difficult. See the many examples cited in Shleifer (2000).
} 
operative, while the sensitivity to any residual component would not. To test this finer prediction we combine the two approaches, using future returns as a cleaner proxy for $\delta$ and closed capital markets as an instrument for the existence of mispricing:

$$
F D I_{i j t}=\hat{a}+\left(\hat{b}_{4} C A C_{i t}+\hat{c}_{i}\right) \cdot \frac{\hat{M}}{B}+e_{i t} .
$$

As before, $b_{4}$ is not a direct estimate of $b$, but if it is positive, we infer that the component of market-to-book that reflects mispricing has a greater impact on FDI than the component that reflects fundamentals. And again, other theories of FDI do not make predictions for $b_{4}$.

\section{B. FDI Data}

Direct investment is distinguished from other international capital flows by the degree to which the investor owns and controls the foreign enterprise. To be precise, some definitions are useful. Direct investment is typically defined as the direct or indirect ownership or control by a single domestic legal entity (the parent) of at least ten percent of the voting securities of an incorporated foreign business enterprise or the equivalent interest in an unincorporated foreign business enterprise (the foreign affiliate). Direct investment flows are then the funds that parents provide to their affiliates net of the funds affiliates provide to their parents.

Direct investment flows are of three types: equity capital, intercompany debt, and reinvested earnings. ${ }^{12}$ Equity capital flows include payments between parents and third parties that occur when parents change their ownership interests, as well as changes in the equity capital contribution of parents to affiliates that are wholly owned. These flows therefore capture the movement of capital used for mergers and acquisitions. Intercompany debt flows occur when

\footnotetext{
${ }^{12}$ The results below are for FDI inclusive of retained earnings. The results are driven entirely by the more active component of FDI. In other words, removing retained earnings from the dependent variable leads to the same conclusions (results available on request).
} 
parents alter the level of their net outstanding loans and trade accounts with the affiliate. Reinvested earnings are the parents' claim on the current-period undistributed after-tax earnings of affiliates. Direct investment positions (i.e., stocks not flows) are the parents' net financial claims on their affiliates, whether these claims take the form of equity or debt. ${ }^{13}$

Our main FDI data set is drawn from the results of the Survey of US Direct Investment Abroad and the Survey of Foreign Direct Investment in the United States, both conducted by the US Bureau of Economic Analysis (BEA). We use a sample that includes information on the position and flow of FDI into and out of the US each year from 1974 through $2001 .^{14}$ These data have some attractive features for us. The panel of flows to and from the 19 countries for which we also have stock market data (described below) is reasonably complete. These data have also been collected on a consistent basis over time-across source countries for FDI into the US, and across hosts for FDI out of the US. Using the BEA data, we measure FDI flows as percentages of the initial FDI position:

$$
F D I_{i j t}=\frac{\text { Flow }_{t}^{i \rightarrow j}}{\text { Position }_{t-1}^{i \rightarrow j}},
$$

where $i$ is the source country is and $j$ is the host. Since small initial positions can lead to outliers in this measure, we truncate it at +100 percent. $^{15}$

\footnotetext{
${ }^{13}$ For additional details on how FDI flows and positions are defined, see Borga (2003).

${ }^{14}$ Because those who do not comply with their survey requests are subject to fines and imprisonment, and because companies are reassured that the "use of an individual company's data for tax, investigative, or regulatory purposes is prohibited," the BEA believes that these data are reasonably complete and accurate.

${ }^{15}$ Like Caves (1989), we scale flows by initial country-specific stocks. Froot and Stein (1991) scale flows by GNP and Dewenter (1995) scales M\&A flows into the US by domestic acquisition activity. Scaling by initial position renders the FDI measure more comparable across countries. This is not important in regressions where we include country fixed effects. In such regressions, we have verified that the results are essentially unchanged when we scale by GDP. In regressions containing future returns, however, such as those along the lines of eq. (5), we prefer not to use country fixed effects. We are interested in whether FDI is especially high when future returns are low. With country fixed effects, an alternative and less interesting interpretation would be that future FDI is low when future returns are low, since demeaned FDI is high. To avoid this ambiguity, we scale by initial stocks and leave out country fixed effects in the regressions motivated by eq. (5).
} 
FDI is notoriously difficult to measure; to determine robustness, we also use two other FDI data sets. One is based on mergers and acquisitions data from Securities Data Company (SDC). As noted in Nocke and Yeaple (2003) and United Nations Center for Transnational Corporations (1999), a large fraction of FDI flows are due to cross-border mergers and acquisitions. The SDC sample includes transactions in which a US firm is either the target or the acquirer and covers 1978 through 2001, although the first half of the sample appears incomplete. ${ }^{16}$ We measure M\&A-based FDI from the US to the UK, for example, as the number of acquisitions by US firms of UK firms divided by the initial number of US affiliates in the UK. The latter is taken from the BEA and is available from 1984 through 1999.

We also use a panel of FDI flows and positions from the OECD International Direct Investment Statistics database. These data include the outflows and outward position of OECD countries' FDI with respect to a broad set of host countries, not only OECD members. This sample covers 1980 through 2001. Although these data would appear to have an advantage in coverage, data for many country pairs are missing, and there are significant differences in how different countries collect and report their data. Nonetheless, results from these data may provide a useful sense of robustness when viewed alongside those from the other data sources. We measure FDI flows in these data as in eq. (10).

The FDI data are summarized in Panel A of Table 1. The BEA data contains 407 (439) observations on FDI inflows into (outflows from) the US, or an average of 21.4 (23.1) years of data for each of the 19 non-US countries for which we also have consistent stock market data. The average annual FDI flows into the US from one of these countries increases its initial

\footnotetext{
${ }^{16}$ One advantage of these data is that acquirer firms are classified by their country of origin. Therefore if a firm uses a holding company outside of its home country to buy a firm in the US, we can classify this transaction as taking place between the acquirer's home country and the US. The FDI flow and position data do not trace investment back to the country of parent origin.
} 
position by 20.30 percent. Likewise, on average, the annual FDI flow from the US to one of these countries increases its initial position by 11.56 percent. Mean M\&A activity is significantly higher for transactions involving a US acquirer, increasing their number of affiliates by 13.83 percent per year, than for transactions involving a US target, at 3.53 percent of lagged affiliates. Mean flows from OECD members amount to 23.36 percent of their initial positions.

\section{Stock market valuations and returns}

Stock market valuations and returns for 19 non-US countries are from Ken French's website. ${ }^{17}$ His data include country-year observations of the capitalization-weighted market-tobook-equity ratio and stock market returns in both dollars and local currency over the 1975-2001 period. For details of the construction of these variables see Fama and French (1998). ${ }^{18}$ We merge in US values, taking the market-to-book ratio on the S\&P 500 from Compustat and returns on the S\&P 500 from the CRSP database. Panel B of Table 1 reports summary statistics.

\section{Country characteristics and controls}

Other data come from a variety of sources. The return on equity, weighted across publicly-traded firms by book value, is from Ken French’s website. The real exchange rate is calculated using nominal exchange rates and price indices from the IMF International Financial Statistics. The exchange rate series are indexed so that the dollar exchange rate in 1975 is set to 1 in each country. Gross domestic product and GDP per capita in 1995 US dollars are from the

\footnotetext{
${ }^{17}$ http://mba.tuck.darmouth.edu/pages/faculty/ken.french/data_library.html.

${ }^{18}$ The raw data are from Morgan Stanley’s Capital International Perspectives (MSCI). The set of firms whose data is used to construct country-level returns and profitability variables is essentially the set of firms included in Morgan Stanley's stock index for that country. These tend to be large firms, and for a typical country they in total cover roughly 80 percent of the domestic stock market's invested wealth. Depending on the country and year, data are based on a minimum of a few dozen large firms to a maximum of several hundred; see Fama and French (1998), Table I. As discussed there, there is little issue of survivor bias in these data.
} 
World Bank’s World Development Indicators. Statutory corporate income tax rates are from the World Tax Database maintained by the Office of Tax Policy Research at the University of Michigan. ${ }^{19}$ These are the maximum marginal statutory corporate tax rates in that country-year. Capital account closedness is based on the index of Brune et al. (2001), which tabulates restrictions on nine kinds of capital account transactions. (The Brune et al. openness index equals the number of transactions that are not significantly restricted; we count the number that are restricted to form a closedness index, to better match the econometric derivation.) Panel C of Table 1 reports summary statistics.

\section{Empirical results}

\section{A. Valuation levels}

Table 2 starts with simple regressions, in the spirit of eq. (2), to document the basic correlations between FDI and stock market valuations. The dependent variables are the BEA measures of FDI into and out of the US. The independent variables of interest are the source and host country market-to-book ratios. To the extent that market-to-book captures misvaluation, the cheap capital story predicts that the coefficient on the market-to-book of the source country stock market will be positive, while the cheap asset story predicts that the coefficient on the market-tobook of the host country will be negative. But as discussed above, because market-to-book also picks up omitted determinants of FDI, Table 2 is not a precise test of our hypotheses, but more of a first step to document some basic relationships. At the same time, just determining the raw effects of source and host stock market valuations will yield some new insights, as prior work on FDI has looked only at relative market valuations.

\footnotetext{
${ }^{19}$ http://wtdb.org/index.html.
} 
The BEA data, while preferable for other reasons, are not well suited to testing the cheap capital and cheap assets stories simultaneously. For instance, in the left columns of Table 2, which study FDI into the US from 19 source countries, the source country valuations vary each country-year, but the host (the US) valuations vary only yearly, and so their effect cannot be estimated at all in the presence of year effects. Similarly, in the right columns, which examine FDI out of the US, host valuations vary at the observation level but source (the US) valuation effects are estimated only from the fairly short time series. Given this 'shape' of the data, we will rely on FDI into the US to examine the cheap capital story, and we'll use FDI out of the US to test the cheap assets story.

The specifications in Table 2 are reminiscent of standard investment- $Q$ equations used to study investment within countries, except that we can separately study the source and host country valuations. Caves (1989) and Klein and Rosengren (1994) consider the ratio of source and host valuations, but we are interested in whether one effect dominates. We also control for a range of other determinants of FDI. Froot and Stein (1991) and Blonigen (1997) find that real exchange rates affect FDI flows into the US. We include the return on equity, as a measure of cash flow is often included alongside Tobin's $Q$ in investment equations. Fazarri, Hubbard, and Petersen (1988) and Lamont (1997) find that investment increases in internal finance, perhaps because external finance is more costly. The relative return on equity in the source and host countries also proxies for the relative attractiveness of fundamental investment opportunities. We include the log of GDP and GDP per capita to capture country size and wealth. Desai, Foley, and Hines (2004) find that US multinationals move capital toward low tax locations, so we include corporate tax rates. Finally, many countries impose capital account restrictions. We include an index of restrictions based on Brune et al. (2001). In addition to these controls, we use country 
and sometimes year effects. Factors like distance and other country fixed effects are motivated by models of FDI based in trade theory.

The specifications in the left panels of Table 2 exploit heterogeneity of conditions across countries investing in the US. They provide preliminary support for the cheap capital hypothesis. The coefficients on the source country market-to-book are reliably positive and significant, irrespective of control variables and fixed effects. The coefficients are also large. The standard deviation of non-US market-to-book ratios is 0.97 , so a one standard deviation increase in source country market-to-book leads to a six to nine percentage point increase in FDI into the US. This compares to a mean inflow of 20.30 percentage points.

Prior studies of FDI flows into the US, including Froot and Stein (1991) and Blonigen (1997), find a negative coefficient on real exchange rates. We do not find a consistent effect. This appears to be due to the sample period. Froot and Stein's (1991) sample, for example, begins in 1973 and ends in 1988. When we focus on this period in our own data, we also find a negative coefficient. However, our data continue through 2001, and the negative correlation between FDI into the US and the real exchange rate breaks down in this segment. In the late 1980’s and early 1990’s, the dollar fell but FDI inflows also declined. More recently, the dollar has strengthened and inflows reached record levels. Klein et al. (2002) also note the apparent breakdown of this relationship.

The right panels of Table 2 analyze FDI out of the US to 19 host countries. Country-year level variation in host country conditions allow for a preliminary assessment of the cheap assets view. The results provide little support for this hypothesis: The coefficients on the host country 
market-to-book are weak and positive, not strong and negative. The most robust coefficient is the negative effect of host country corporate taxes, consistent with Desai et al. (2004). ${ }^{20}$

Table 3 reproduces these specifications with other FDI data sets. The first two panels consider cross-border merger and acquisition transactions that involve a US firm as acquirer or target. We measure M\&A into the US from a particular country as the number of US firms acquired by firms from that country. We scale this by the total number of US affiliates of firms in the source country at the start of the year. M\&A activity out of the US to a particular country is the number of firms in a host country acquired by US firms, again scaled by the number of affiliates of US firms in that country at the start of the year.

The results confirm our initial findings. In the left columns, the coefficients on the source country market-to-book ratio are positive and significant, indicating that acquisitions of US firms increase when overseas stock markets are highly valued. This is consistent with the Shleifer and Vishny (2003) theory of mergers and acquisitions. In the right columns, however, we again see no support for the idea that cross-border M\&A is driven by low valuations of the target. However, US firms’ overseas acquisition activity does appear to be strongly dependent upon US valuations, also consistent with the cheap capital hypothesis, although this effect is estimated from only a fairly short time series.

The last panel of Table 3 studies a panel of bilateral FDI outflows among 20 developed countries from the OECD International Direct Investment Statistics. While these data are subject to some concern about comparability across countries and time, in principle they allow us to simultaneously consider the cheap capital and cheap asset hypotheses in a broad sample. The

\footnotetext{
${ }^{20}$ The results here and in all subsequent tables are unchanged when we control for short- or long-term government interest rates using data from the Global Financial Database (results available upon request). However, since we could obtain interest rates only for 85 to 90 percent of our sample, we do not include them in these regressions.
} 
results here are essentially identical to those from the US-based data sets: source country valuations have a strong and positive influence on FDI, while host valuations are unimportant.

Summing up, the analysis so far demonstrates a new fact about FDI flows: there is a very strong positive link between source country stock market valuations and FDI, potentially consistent with a cheap capital view of FDI. The other result thus far is the lack of evidence of “fire-sale FDI.” However, one must keep in mind the nature of our sample. Our stock market data cover 20 mostly developed countries. While developed countries account for the vast majority of the world's FDI flows [Feenstra (1999)], they may not provide the most powerful sample for testing the cheap assets view. Developing countries may be more prone to the extreme economic fluctuations that create conditions for fire sale FDI, and the existing evidence on the cheap assets view, Agiuar and Gopinanth (2003), uses samples exclusively from emerging markets. Hence, the strongest statement we can make is that cheap assets motives are unlikely to be important as a general determinant of FDI.

\section{B. Fundamental and non-fundamental valuations}

We now take a closer look at the positive correlation between source country valuations and FDI. While at face value this correlation is consistent with the cheap capital hypothesis, it is also consistent with many other explanations, reflecting the fact that stock market valuations pick up not just misvaluation but also many omitted fundamental determinants of investment. Here we use future stock returns as an instrument for the component of market-to-book that reflects mispricing, the identifying approach discussed in eqs. (4) and (5). For brevity, we focus on the 
BEA data on FDI flows into the US, which offers the most variation in source country valuations. $^{21}$

As discussed in the methodology section, the idea behind this approach is that mispricing ex ante is can be detected from the returns that correct the mispricing ex post. If future returns are negatively correlated with ex ante mispricing and otherwise uncorrelated with measurement error in market-to-book, the fitted values from the first stage serve as a purer measure of mispricing. The first stage regression of market-to-book on one-year-ahead dollar returns yields

$$
\frac{\hat{M}}{B}_{i t}=1.82-0.72 R_{i t+1},
$$

with 426 observations and a heteroskedasticity robust t-statistic of 5.07. The residual, and more likely fundamental, component of the market-to-book ratio is

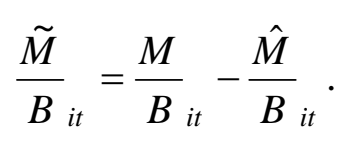

Clearly, in decomposing valuations into fundamental and non-fundamental components like this, we are imposing the assumption that mispricing is corrected over the next year. As a result, a portion of the mispricing component of valuations may remain in the residuals in eq. (12). If so, the decomposition would be conservative.

Table 4 reports the second stage, revealing that FDI flows are positively related to both the fundamental and nonfundamental components of stock market valuations. ${ }^{22}$ Note that the latter coefficient implicitly shows that FDI predicts lower returns in the source stock market.

\footnotetext{
${ }^{21}$ A broader set of results is available upon request.

${ }^{22}$ Of course, we could simply put future returns in the second stage regression, but using fitted values allows the reader to compare the coefficients in Table 5 with those in Table 2.
} 
This is difficult to explain within existing theories of FDI, rooted in rational expectations and efficient and integrated world capital markets. ${ }^{23}$

The nonfundamental coefficient in Table 4 is about 2.5 times as large as the residual M/B coefficient. (F-tests indicate that this difference is significant at the 10 percent level in the last two specifications.) Both effects remain strong when additional controls and year effects are included. Since the standard deviation of the nonfundamental component of M/B is only 21 percent that of the residual component, a very rough estimate of overall economic significance would be that, according to this methodology, mispricing appears half (2.5 times 0.21 equals 0.52) as important as the fundamental component of source country valuations in explaining FDI flows. This strikes us as a magnitude that is both interesting and believable.

\section{Limits to cross-market arbitrage}

While the future returns results seem highly suggestive that FDI increases when capital is cheap, they do not completely rule out a spurious correlation. The key identifying assumption is that future returns are uncorrelated with omitted country characteristics that influence FDI. However, in a somewhat convoluted story, a technology shock could simultaneously cause FDI outflows and an overvalued stock market. For instance, asset price bubbles sometimes appear in times of rapid technological change.

\footnotetext{
${ }^{23}$ Table 5 is structured to emphasize the determinants of FDI, but we have explicitly confirmed the implication that FDI flows into the US could be used to predict source country returns (with a negative sign). A table is available on request. We have also verified that these results are not driven by the small-sample bias in return prediction regressions discussed in Nelson and Kim (1993), Kothari and Shanken (1997), and Stambaugh (1999). That is, when the independent variable is persistent and its innovations are correlated with the dependent variable, its predictive power will be overstated in an OLS regression. Fortunately, the FDI series are not highly persistent (the average country autocorrelation is 0.06; only three are significantly positive) and innovations are uncorrelated with contemporaneous returns (the average correlation is 0.12 ; only one is significantly positive).
} 
As discussed in the methodology section, we address this objection by testing whether the effect of source country valuations is more pronounced where capital account restrictions are most severe. The idea is that such restrictions limit cross-market arbitrage, making extreme values of market-to-book in the presence of such restrictions more likely to reflect mispricing. Put differently, we can use capital account closedness as an instrument for the existence of mispricing, not the direction.

Table 5 reports regressions in which we interact valuation ratios with an index of capital account restrictions based on Brune et al. (2001). In Tables 5 and 6, we standardize this variable to have zero mean and unit variance. The left columns show that capital account restrictions tend to increase the effect of source country market-to-book, with a significant effect in the first specification and a marginally significant effect in the second. The interaction is not significant in the third specification. (Remember that, as discussed in more detail in the methodology section, this test can only detect an effect if the coefficient on the mispricing component of $\mathrm{M} / \mathrm{B}$ is actually larger than the fundamental piece. Hence, an insignificant result is not a rejection of the premise.) However, an F-test reveals that this specification implies that at the lowest level of the capital account restrictions index, which characterizes slightly less that 10 percent of the sample, the source country aggregate market-to-book-value ratio is no longer a significant determinant of FDI.

The effect of capital account restrictions comes through more sharply when we combine empirical strategies, using future returns to hone in on the mispricing component of market-tobook and looking at the effect of that component in the presence of capital account restrictions. The results are in the right columns of Table 5. In each of these specifications, the coefficients on the fitted component of source market-to-book, and on its interactions with capital account 
restrictions, are positive and significant. Meanwhile, the coefficients on the fundamental component of valuations are positive and significant, but the interaction terms are not. This pattern of results accords closely with predictions. It suggests that the strategy of using capital account restrictions and future returns to identify mispricing is successful, and represents fairly convincing evidence that FDI is increased by the presence of cheap capital. ${ }^{24}$

One potential source of confusion is that capital account restrictions take several forms, including restrictions on FDI outflows. While we already control for restrictions directly, it is useful to verify that the interaction results in Table 5 come about through the ability of CAC to identify mispricing and not through a mechanical (nonlinear) effect on FDI. Table 6 investigates this issue using alternative indices of capital account restrictions. We consider three alternative indices. One specifically excludes any FDI restrictions (both inward and outward); one includes only outward FDI restrictions; and one includes only restrictions on capital and money market securities. Excluding FDI restrictions makes little difference to the interaction coefficients, compared to those reported in Table 5. Likewise, an index based solely on restrictions on FDI outflows has no interesting interactive effects. This confirms that restrictions on FDI outflows are not driving the effects documented earlier. Rather, much of the effect of the overall index appears to be coming through capital market restrictions, as suggested in the last columns of Table 6. This again is nicely consistent with the capital market mispricing hypothesis.

\section{Conclusion}

A substantial literature has examined the link between securities market mispricing and corporate investment patterns, but a consensus has not emerged. In this paper, we ask whether

\footnotetext{
${ }^{24}$ We find similar results if the capital control indicator from the IMF is used in place of the Brune et al. (2001) measure.
} 
and how mispricing affects foreign direct investment. Prior research has not considered FDI from this perspective, but FDI actually offers a rich laboratory in which to look for economic effects of mispricing. In particular, we exploit country-year level variation in stock market valuations, realized returns (which contain ex post information about ex ante mispricing), and limits to cross-market arbitrage, to develop a series of more powerful and potentially more revealing tests than were available to prior, within-country studies.

The results of all of our tests point to the same conclusion: source country mispricing is important for FDI, but host country mispricing is not. Put simply, overpriced stock markets push out FDI, but underpriced stock markets do not pull it in. We perform several exercises to hone in on the specific component of source-country stock market valuations that constitutes mispricing, and to confirm that it is indeed this component that has the strongest effect on FDI outflows. In sum, the results point to the existence of a novel "cheap capital" or cost-of-capital influence on FDI. Since most existing theories of FDI follow Hymer (1960) in assuming that international capital markets are informationally efficient and integrated, we suggest that the cheap capital view offers a realistic and potentially useful addition to that literature. At the same time, the results also provide indirect evidence that cost of capital motives may be an important reason why investment and stock prices are positively correlated within countries. 


\section{References}

Aguiar, Mark, and Gita Gopinath, 2003, Fire-sale FDI and liquidity crises, University of Chicago working paper.

Asquith, Paul and David W. Mullins, 1986, Equity issues and offering dilution, Journal of Financial Economics 15, 61-89.

Baker, Malcolm, Jeremy C. Stein, and Jeffrey Wurgler, 2003, When does the market matter? Stock prices and the investment of equity-dependent firms, Quarterly Journal of Economics 118, 969-1006.

Baker, Malcolm, and Jeffrey Wurgler, 2000, The equity share in new issues and aggregate stock returns, Journal of Finance 55, 2219-2257.

Barberis, Nicholas, and Richard Thaler, 2003, A survey of behavioral finance, in George Constantinides, Milton Harris, and Rene Stulz, eds., Handbook of the Economics of Finance, (Amsterndam: North-Holland).

Barro, Robert J., 1990, The stock market and investment, Review of Financial Studies 3, 115132.

Basu, Saniov, 1983, The relationship between earnings' yield, market value and return for NYSE common stocks: Further evidence, Journal of Financial Economics 12, 129-56.

Bekaert, Geert, 1995, Market integration and investment barriers in emerging equity markets, World Bank Economic Review 9, 75-107.

Bekaert, Geert, and Campbell R. Harvey, 1995, Time-varying world market integration, Journal of Finance 50, 403-444.

Bernanke, Ben S., and Mark Gertler, 1995, Inside the black box: The credit channel of monetary transmission, Journal of Economic Perspectives 9, 27-48.

Bernanke, Ben S., Mark Gertler, and Simon Gilchrist, 2000, The financial accelerator in a quantitative business cycle framework, in John Taylor and Michael Woodford, eds., Handbook of Macroeconomics, (Amsterdam: North-Holland).

Blanchard, Olivier, Chanyong Rhee, and Lawrence Summers, 1990, The stock market, profit, and investment, Quarterly Journal of Economics 105, 115-136.

Blonigen, Bruce A., 1997, Firm-specific assets and the link between exchange rates and foreign direct investment, American Economic Review 87, 447-465. 
Blonigen, Bruce A., Ronald B. Davies, and Keith Head, 2003, Estimating the knowledge-capital model of the multinational enterprise: Comment, American Economic Review 93, 980994.

Bodurtha, James N., Jr., Dong-Soon Kim, and Charles M. C. Lee, 1995, Closed-end funds and U.S. market sentiment, Review of Financial Studies 8, 879-918.

Borga, Maria, 2003, Direct investment positions for 2002, Survey of Current Business July, 2231.

Brainard, S. Lael, 1997, An empirical assessment of the proximity-concentration trade-off between multinational sales and trade, American Economic Review 87, 520-544.

Brav, Alon, and Paul A. Gompers, 1997, Myth or reality? The long-run underperformance of initial public offerings: Evidence from venture capital and nonventure capital-backed companies, Journal of Finance 52, 1791-1822.

Brune, Nancy, Geoffrey Garrett, Alexandra Guisinger, and Jason Sorens, 2001, The political economy of capital account liberalization, Yale University working paper.

Brunnermeier, Markus, and Stefan Nagel, 2004, Hedge funds and the technology bubble, Journal of Finance 59 (forthcoming).

Carr, David L., James Markusen, and Keith Maskus, 2001, Estimating the knowledge-capital model of the multinational enterprise, American Economic Review 91, 699-708.

Caves, Richard E., 1989, Exchange-rate movements and foreign direct investment in the United States, in D. B. Auerbach and M. P. Claudon, eds.: The Internationalization of U.S. Markets, 199-228, (NYU Press, New York).

Caves, Richard E., 1999, Multinational Enterprise and Economic Analysis, (Cambridge University Press, Cambridge, UK).

Chirinko, Robert S., and Huntley Schaller, 2001, Business fixed investment and 'bubbles': The Japanese case, American Economic Review 91, 663-680.

Chirinko, Robert S., and Huntley Schaller, 2004, Glamour vs. value: The real story, Emory University working paper.

Desai, Mihir, C. Fritz Foley, and James R. Hines, Jr., 2004, Foreign direct investment in a world of multiple taxes, Journal of Public Economics (forthcoming).

Dewenter, Kathryn, 1995, Do exchange rate changes drive foreign direct investment? Journal of Business 68, 405-33. 
Dong, Ming, David Hirshleifer, Scott Richardson, and Siew Hong Teoh, 2003, Does investor misvaluation drive the takeover market?, Ohio State University working paper.

Fama, Eugene F., 1998, Market efficiency, long-term returns, and behavioral finance, Journal of Financial Economics 49, 283-306.

Fama, Eugene F., and Kenneth R. French, 1992, The cross-section of expected stock returns, Journal of Finance 47, 427-465.

Fama, Eugene F., and Kenneth R. French, 1998, Value versus growth: The international evidence, Journal of Finance 53, 1975-1999.

Fazzari, Steven M., R. Glenn Hubbard, and Bruce C. Petersen, 1988, Financing constraints and corporate investment, Brookings Papers on Economic Activity 1, 141-195.

Feenstra, Robert C., 1999, Facts and fallacies about foreign direct investment, in Martin Feldstein, ed.: International Capital Flows, (University of Chicago Press, Chicago, Ill.).

Fisher, Stanley, and Robert C. Merton, 1984, Macroeconomics and finance: The role of the stock market, Carnegie-Rochester Conference Series on Public Policy 21, 57-108.

Frankel, Richard, and Charles M. C. Lee, 1998, Accounting valuation, market expectation, and cross-sectional stock returns, Journal of Accounting and Economics 25, 283-319.

Froot, Kenneth A., and Emil M. Dabora, 1999, How are stock prices affected by the location of trade? Journal of Financial Economics 53, 189-216.

Froot, Kenneth A., and Jeremy C. Stein, 1991, Exchange rates and foreign direct investment: An imperfect capital markets approach, Quarterly Journal of Economics 106, 1191-1217.

Gilchrist, Simon, Charles P. Himmelberg, and Gur Hubberman, 2003, Do stock price bubbles influence corporate investment?, Columbia Business School working paper.

Gordon, Roger H., and James R. Hines, Jr., forthcoming, International taxation, in Alan J. Auerbach and Martin Feldstein, eds., Handbook of Public Economics 4 (Amsterdam: Elsevier).

Graham, John R., and Campbell R. Harvey, 2001, The theory and practice of corporate finance: Evidence from the field, Journal of Financial Economics 60, 187-243.

Hardouvelis, Gikas, Rafael La Porta, and Thierry A. Wizman, 1994, What moves the discount on closed-end country funds?, in Jeffrey Frankel, ed.: The Internationalization of Equity Markets (University of Chicago Press, Chicago, Ill.).

Helpman, Elhanan, 1984, A simple theory of international trade with multinational corporations, Journal of Political Economy 92, 451-471. 
Henry, Peter, 2000, Do stock market liberalizations cause investment booms? Journal of Financial Economics 58, 529-64.

Hymer, Stephen Herbert, 1976, The International Operations of National Firms: A Study of Direct Foreign Investment (MIT Press, Cambridge, MA), MIT Department of Economics $\mathrm{PhD}$ thesis originally presented 1960.

Jung, Kooyul, Yong Cheol Kim, and Rene M. Stulz, 1996, Timing, investment opportunities, managerial discretion, and the security issue decision, Journal of Financial Economics 42, 159-185.

Keynes, John Maynard, 1936, The General Theory of Employment, Interest, and Money, London: Macmillan.

Klein, Michael W., Joe Peek, and Eric Rosengren, 2002, Troubled banks, impaired foreign direct investment: The role of relative access to credit, American Economic Review 92, 664682.

Klein, Michael W., and Eric Rosengren, 1994, The real exchange rate and foreign direct investment in the United States, Journal of International Economics 36, 373-389.

Kothari, S.P., and Jay Shanken, 1997, Book-to-market, dividend yield, and expected market returns: A time-series analysis, Journal of Financial Economics 44, 169-203.

Krugman, Paul, 1998, Fire-sale FDI, Princeton University note.

La Porta, Rafael, 1996, Expectations and the cross-section of stock returns, Journal of Finance 51 1715-1742.

La Porta, Rafael, Josef Lakonishok, Andrei Shleifer, and Robert Vishny, 1997, Good news for value stocks: Further evidence on market efficiency, Journal of Finance 859-874.

Lamont, Owen, 1997, Cash flow and investment: Evidence from internal capital markets, Journal of Finance 52, 83-109.

Lamont, Owen, and Richard Thaler, 2003, Can the market add and subtract? Mispricing in tech stock carve-outs, Journal of Political Economy 111, 227-268.

Loughran, Tim, and Jay Ritter, 1995, The new issues puzzle, Journal of Finance 50, 23-51.

Loughran, Tim, Jay Ritter, and Kristian Rydqvist, 1994, Initial public offerings: International insights, Pacific-Basin Finance Journal 2, 165-199.

Markusen, James R., 1984, Multinationals, multi-plant economies, and the gains from trade, Journal of International Economics 16, 205-226. 
Markusen, James R., 1997, Trade versus investment liberalization, NBER working paper.

Markusen, James R., Anthony J. Venables, Denise Eby Konan, and Kevin Zhang, 1996, A unified treatment of horizontal direct investment, vertical direct investment, and the pattern of trade in goods and services, NBER working paper.

Marsh, Paul, 1982, The choice between equity and debt: An empirical study, Journal of Finance 37, 121-144.

Mitchell, Mark, Todd Pulvino, and Erik Stafford, 2002, Price pressure around mergers, Journal of Finance 59, 31-63.

Morck, Randall, Andrei Shleifer, and Robert Vishny, 1990, The stock market and investment: Is the market a sideshow? Brookings Papers on Economic Activity 2, 157-215.

Nelson, Charles and M. Kim, 1993, Predictable stock returns: The role of small-sample bias, Journal of Finance 48, 641-661.

Nocke, Volker, and Stephen R. Yeaple, 2003, Mergers and the composition of international commerce, University of Pennsylvania working paper.

Pagano, Marco, Fabio Panetta, and Luigi Zingales, 1998, Why do companies go public? An empirical analysis, Journal of Finance 53, 27-64.

Polk, Christopher, and Paola Sapienza, 2003, The real effects of investor sentiment, Northwestern University, working paper.

Pontiff, Jeffrey, and Lawrence D. Schall, 1998, Book-to-market as a predictor of market returns, Journal of Financial Economics 49, 141-160.

Pulvino, Todd C., 1998, Do asset fire sales exist? An empirical investigation of commercial aircraft transactions, Journal of Finance 53, 939-978.

Richardson, Scott A., and Richard G. Sloan, 2003, External financing and future stock returns, University of Pennsylvania working paper.

Ritter, Jay, 1991, The long-run performance of initial public offerings, Journal of Finance 42, 365-394.

Rosenthal, Leonard, and Colin Young, 1990, The seemingly anomalous price behavior of Royal Dutch/Shell and Unilever N.V./PLC, Journal of Financial Economics 26, 123-41.

Shleifer, Andrei, 2000, Inefficient Markets: An Introduction to Behavioral Finance, (Oxford University Press, Oxford). 
Shleifer, Andrei, and Robert W. Vishny, 1992, Liquidation values and debt capacity: A market equilibrium approach, Journal of Finance 47, 1343-1366.

Shleifer, Andrei, and Robert W. Vishny, 2003, Stock market driven acquisitions, Journal of Financial Economics 70, 295-312.

Speiss, D. Katherine, and John Affleck-Graves, 1995, Underperformance in long-run stock returns following seasoned equity offerings, Journal of Financial Economics 38, 243267.

Stambaugh, Robert F, 1999, Predictive regressions, Journal of Financial Economics 54, 375421.

Stein, Jeremy C., 1996, Rational capital budgeting in an irrational world, Journal of Business 69 429-455.

Stein, Jeremy C., 2004, Why are most funds open-end? Competition and the limits of arbitrage, NBER working paper.

Stigler, George J., 1964, Public regulation of the securities markets, Journal of Business 37, 117142.

United Nations Center for Transnational Corporations, 1999, World Investment Report.

Verter, Geoffrey, 2003, Timing merger waves, Harvard University working paper.

Yeaple, Stephen, 2003, The complex integration strategies of multinationals and cross-country dependencies in the structure of foreign direct investment, Journal of International Economics 60, 293-314. 
Table 1. Summary Statistics. Means, medians, standard deviations, and extreme values for foreign direct investment, stock market valuations and returns, and country characteristics. Panel A summarizes three sources of data on foreign direct investment. FDI ${ }_{i U S t}$ and FDI $_{U S i t}$ are from the Bureau of Economic Analysis and report annual FDI flows in which the US is the host or the source country, respectively. FDI flows are measured here as the gross FDI flow as a percentage of the beginning of year stock. M\& $A_{i U S t}$ and $M \& A_{i U S t}$ are from SDC and measure crossborder mergers and acquisitions activity involving US firms as targets or acquirers, respectively. M\&A flows are expressed as the number of new affiliates acquired as a percentage of the number of affiliates existing at the beginning of the year. $\mathrm{FDI}_{i j t}$ is a full panel of bilateral FDI flows among developed countries from OECD International Direct Investment Statistics. FDI flows are measured here as the gross FDI flow as a percentage of the beginning of year stock. Panel B shows stock market valuations and returns data. International stock market returns in dollar and local terms, $\mathrm{R}_{i t}$, and the average market-equity-to-book-equity ratio of public firms, $\mathrm{M} / \mathrm{B}_{i t}$, are from Ken French's website and are based on data from Morgan Stanley's Capital International Perspectives (MSCI). We use the S\&P 500 return from CRSP and the S\&P 500 market-to-book ratio from Compustat to merge in US values. Panel C summarizes country characteristics and control variables for a sample of country-years that represents the intersection between the stock market data and the BEA data on FDI into the US. For non-US countries, the return on equity $\mathrm{ROE}_{i}$ is from Ken French's website and based on MSCI data. US values for the S\&P 500 are from Compustat. The real exchange rate is from IMF International Financial Statistics and is in units of foreign currency per US dollar, with the index set to 1 for 1975. GDP and GDP per capita measured in constant 1995 US dollars are from the World Bank's World Development Indicators. Non-US income tax rates $\operatorname{Tax}_{i}$ are from the World Tax Database maintained by the Office of Tax Policy Research at the University of Michigan. US income tax rates are from the NBER. The index of capital account closedness CAC $_{i t}$ is from Brune et al. (2001).

\begin{tabular}{|c|c|c|c|c|c|c|}
\hline & $\mathbf{N}$ & Mean & Median & SD & Min & Max \\
\hline & \multicolumn{6}{|c|}{ Panel A. Foreign direct investment } \\
\hline $\mathrm{FDI}_{i U S t}(\%)$ & 407 & 20.30 & 16.29 & 26.91 & -70.97 & 100.00 \\
\hline $\mathrm{FDI}_{U S i t}(\%)$ & 439 & 11.56 & 9.60 & 13.94 & -33.78 & 100.00 \\
\hline$M \& A_{i U S t}(\%)$ & 286 & 3.53 & 2.66 & 3.48 & 0.00 & 20.91 \\
\hline$M \& A_{U S i t}(\%)$ & 286 & 13.83 & 8.28 & 17.94 & 0.00 & 100.00 \\
\hline \multirow[t]{2}{*}{$\mathrm{FDI}_{i j t}(\%)$} & 2,706 & 17.49 & 12.15 & 30.25 & -100.00 & 100.00 \\
\hline & \multicolumn{6}{|c|}{ Panel B. Stock market valuations and returns } \\
\hline $\mathrm{M} / \mathrm{B}_{i t}$ & 407 & 1.81 & 1.66 & 0.97 & 0.37 & 9.84 \\
\hline $\mathrm{M} / \mathrm{B}_{U S t}$ & 407 & 3.14 & 2.73 & 1.78 & 1.20 & 7.01 \\
\hline $\mathrm{R}_{i t+1}(\%$, Dollar $)$ & 388 & 15.01 & 11.81 & 29.25 & -47.07 & 135.80 \\
\hline $\mathrm{R}_{i t+1}(\%$, Local $)$ & 388 & 16.14 & 13.76 & 27.08 & -39.42 & 153.67 \\
\hline \multirow[t]{2}{*}{$\mathrm{R}_{U S t+1}(\%$, Dollar $)$} & 388 & 14.91 & 20.42 & 14.77 & -11.09 & 35.71 \\
\hline & \multicolumn{6}{|c|}{ Panel C. Country characteristics and controls } \\
\hline $\mathrm{ROE}_{i t}(\%)$ & 407 & 12.08 & 11.73 & 3.94 & 3.47 & 31.75 \\
\hline $\mathrm{ROE}_{U S t}(\%)$ & 407 & 16.19 & 14.99 & 4.06 & 10.65 & 22.98 \\
\hline Exrate $_{i t}(1975=1)$ & 407 & 1.04 & 1.01 & 0.20 & 0.56 & 1.69 \\
\hline $\mathrm{GDP}_{i t}(\$ \mathrm{~B} 1990)$ & 407 & 803 & 297 & 1,140 & 29 & 5,680 \\
\hline GDP/Cap ${ }_{i t}(\$ 1990)$ & 407 & 24,890 & 23,821 & 8,330 & 10,742 & 47,064 \\
\hline $\operatorname{Tax}_{i t}(\%)$ & 407 & 34.77 & 35.00 & 10.97 & 5.43 & 56.00 \\
\hline $\mathrm{CAC}_{i t}$ & 407 & 3.76 & 3.00 & 2.83 & 0.00 & 9.00 \\
\hline
\end{tabular}


Table 2. FDI and Stock Market Valuations. Regressions of FDI into and out of the US on the local market-to-book ratio, the US market-to-book ratio, and controls. The FDI data are from the BEA. All variables are summarized in Table 1. The first six columns show regressions explaining FDI flows into the US. The second six columns show regressions explaining FDI flows out of the US. Heteroskedasticity robust t-statistics are in braces.

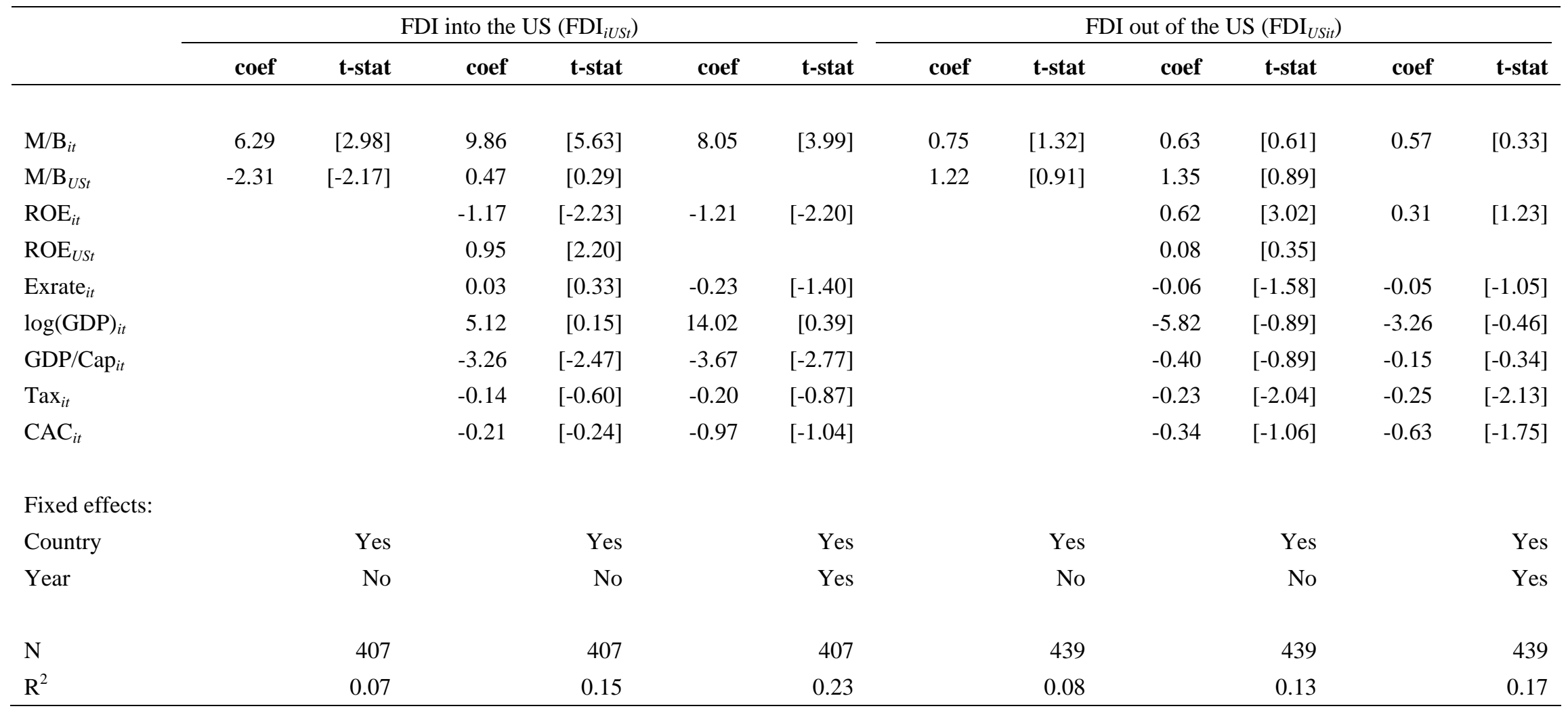


Table 3. FDI and Stock Market Valuations: Alternative Data Sources. The first two panels show regressions of M\&A activity into and out of the US on the local market-to-book ratio, the US market-to-book ratio, and controls. The M\&A data are from the SDC. Panel A shows regressions explaining M\&A activity into the US. Panel B shows regressions explaining M\&A activity out of the US. The last panel shows regressions of FDI between 20 developed countries on the source country market-to-book ratio, the host country market-to-book ratio, and controls. The FDI data are from the OECD. The control variables are return on equity in the source and host country, and the exchange rate, log of GDP, GDP per capita, tax rates, and capital controls in the source country. All variables are summarized in Table 1. Heteroskedasticity robust t-statistics are in braces.

\begin{tabular}{|c|c|c|c|c|c|c|}
\hline & \multicolumn{2}{|c|}{ Excluding controls } & \multicolumn{4}{|c|}{ Including controls } \\
\hline & coef & t-stat & coef & t-stat & coef & t-stat \\
\hline \multicolumn{7}{|c|}{ Panel A. M\&A into the US $\left({\left.\mathrm{M} \& \mathrm{~A}_{i U S t}\right)}\right.$} \\
\hline $\mathrm{M} / \mathrm{B}_{i t}$ & 1.89 & {$[8.36]$} & 1.63 & {$[6.05]$} & 1.64 & [5.61] \\
\hline $\mathrm{M} / \mathrm{B}_{U S t}$ & 0.12 & {$[1.34]$} & -0.18 & {$[1.21]$} & & \\
\hline \multicolumn{7}{|l|}{ Fixed effects: } \\
\hline Country & & Yes & & Yes & & Yes \\
\hline Year & & No & & No & & Yes \\
\hline $\mathrm{N}$ & & 286 & & 286 & & 286 \\
\hline $\mathrm{R}^{2}$ & & 0.74 & & 0.78 & & 0.82 \\
\hline \multicolumn{7}{|c|}{ Panel B. M\&A out of the US $\left(M \& \mathrm{~A}_{U S j t}\right)$} \\
\hline $\mathrm{M} / \mathrm{B}_{j t}$ & 0.59 & {$[0.53]$} & 3.42 & {$[0.35]$} & -0.70 & {$[-0.68]$} \\
\hline $\mathrm{M} / \mathrm{B}_{U S t}$ & 5.56 & {$[10.03]$} & 5.55 & {$[5.69]$} & & \\
\hline \multicolumn{7}{|l|}{ Fixed effects: } \\
\hline Country & & Yes & & Yes & & Yes \\
\hline Year & & No & & No & & Yes \\
\hline $\mathrm{N}$ & & 286 & & 286 & & 286 \\
\hline \multirow[t]{2}{*}{$\mathrm{R}^{2}$} & & 0.69 & & 0.73 & & 0.74 \\
\hline & \multicolumn{6}{|c|}{ Panel C. Bilateral FDI flow $\left(\mathrm{FDI}_{i j t}\right)$} \\
\hline $\mathrm{M} / \mathrm{B}_{i t}$ & 4.14 & [6.73] & 6.13 & {$[5.76]$} & 4.79 & [4.04] \\
\hline $\mathrm{M} / \mathrm{B}_{j t}$ & -0.40 & {$[-0.56]$} & 0.79 & {$[0.88]$} & 0.52 & [0.53] \\
\hline \multicolumn{7}{|l|}{ Fixed effects: } \\
\hline Country ( $i$ and $j$ ) & & Yes & & Yes & & Yes \\
\hline Year & & No & & No & & Yes \\
\hline $\mathrm{N}$ & & 2,706 & & 2,706 & & 2,706 \\
\hline $\mathrm{R}^{2}$ & & 0.06 & & 0.07 & & 0.09 \\
\hline
\end{tabular}


Table 4. FDI and Stock Market Valuations: Fundamental and Non-Fundamental Components. Regressions of FDI into the US on the source country market-to-book ratio, the US market-to-book ratio, and controls. The FDI data are from the BEA. All variables are summarized in Table 1. We decompose the source country market-to-book ratio into a non-fundamental or mispricing component (Fitted $\mathrm{M} / \mathrm{B}_{i t}$ ) and a fundamental component (Residual $\mathrm{M} / \mathrm{B}_{i t}$ ). The decomposition is based on a first stage regression of market-to-book on future returns: Fitted $\mathrm{M} / \mathrm{B}_{i t}=$ $1.82-0.72 \mathrm{R}_{i t+1}(\mathrm{~N}=426, \mathrm{t}-\mathrm{stat}=5.07)$. Heteroskedasticity robust t-statistics are in braces.

\begin{tabular}{|c|c|c|c|c|c|c|}
\hline & \multicolumn{6}{|c|}{ FDI into the US (FDI ${ }_{i U S t}$ ) } \\
\hline & coef & t-stat & coef & t-stat & coef & t-stat \\
\hline Fitted $\mathrm{M} / \mathrm{B}_{i t}$ & 17.58 & {$[2.85]$} & 21.70 & [3.31] & 22.00 & [2.82] \\
\hline Residual M/B & 7.60 & {$[4.54]$} & 9.52 & {$[4.81]$} & 8.72 & [3.28] \\
\hline $\mathrm{M} / \mathrm{B}_{U S t}$ & -2.06 & {$[-2.15]$} & -2.80 & {$[-2.12]$} & & \\
\hline $\mathrm{ROE}_{i t}$ & & & -0.54 & {$[-1.19]$} & -0.61 & {$[-1.27]$} \\
\hline $\mathrm{ROE}_{U S t}$ & & & 0.81 & {$[1.61]$} & & \\
\hline Exrate $_{i t}$ & & & 0.11 & {$[1.54]$} & -0.01 & {$[-0.13]$} \\
\hline $\log (\mathrm{GDP})_{i t}$ & & & 0.38 & {$[0.22]$} & -0.26 & {$[-0.15]$} \\
\hline $\mathrm{GDP} \mathrm{Cap}_{i t}$ & & & -0.50 & {$[-2.65]$} & -0.48 & {$[-2.52]$} \\
\hline $\operatorname{Tax}_{i t}$ & & & -0.06 & {$[-0.41]$} & -0.06 & {$[-0.41]$} \\
\hline CAC $_{i t}$ & & & 0.55 & {$[1.01]$} & 0.17 & {$[0.28]$} \\
\hline \multicolumn{7}{|l|}{ Fixed effects: } \\
\hline Year & & No & & No & & Yes \\
\hline $\mathrm{N}$ & & 388 & & 388 & & 388 \\
\hline $\mathrm{R}^{2}$ & & 0.06 & & 0.10 & & 0.17 \\
\hline
\end{tabular}


Table 5. FDI and Stock Market Valuations: Closed Capital Accounts. Regressions of FDI into the US on the source country market-to-book ratio, the US market-to-book ratio, their interactions with a capital account openness index, and controls. The FDI data are from the BEA. All variables are summarized in Table 1 . We decompose the source country market-to-book ratio into a non-fundamental or mispricing component (Fitted $\mathrm{M} / \mathrm{B}_{i t}$ ) and a fundamental component (Residual $\mathrm{M} / \mathrm{B}_{i t}$ ). The decomposition is based on a first stage regression of market-to-book on future returns: Fitted $\mathrm{M} / \mathrm{B}_{i t}=1.82-0.72 \mathrm{R}_{i t+1}(\mathrm{~N}=426$, $\mathrm{t}-\mathrm{stat}=5.07)$. Market-to-book or its components are then interacted with an index of capital account closedness from Brune et al. (2001) for the second stage regression. CAC is standardized to have zero mean and unit variance. Heteroskedasticity robust t-statistics are in braces.

\begin{tabular}{|c|c|c|c|c|c|c|c|c|c|c|c|c|}
\hline & \multicolumn{12}{|c|}{ FDI into the US (FDI $\left.{ }_{i U S t}\right)$} \\
\hline & \multicolumn{6}{|c|}{$\mathrm{M} / \mathrm{B}$} & \multicolumn{6}{|c|}{ M/B decomposition } \\
\hline & Coef & t-stat & coef & t-stat & coef & t-stat & coef & t-stat & coef & t-stat & coef & t-stat \\
\hline $\mathrm{M} / \mathrm{B}_{i t}$ & 7.95 & {$[3.57]$} & 10.93 & {$[5.16]$} & 8.71 & {$[3.72]$} & & & & & & \\
\hline $\mathrm{M} / \mathrm{B}_{i t} \cdot \mathrm{CAC}_{i t}$ & 4.89 & {$[2.04]$} & 4.43 & {$[1.68]$} & 2.30 & {$[0.88]$} & & & & & & \\
\hline Fitted $\mathrm{M} / \mathrm{B}_{i t}$ & & & & & & & 13.40 & {$[2.00]$} & 18.87 & {$[2.65]$} & 17.07 & {$[2.04]$} \\
\hline Fitted $\mathrm{M} / \mathrm{B}_{i t} \cdot \mathrm{CAC}_{i t}$ & & & & & & & 19.37 & {$[3.26]$} & 22.49 & {$[3.86]$} & 21.51 & [3.35] \\
\hline Residual M/B ${ }_{i t}$ & & & & & & & 8.74 & {$[4.88]$} & 10.77 & {$[5.05]$} & 9.35 & [3.37] \\
\hline Residual $\mathrm{M} / \mathrm{B}_{i t} \cdot \mathrm{CAC}_{i t}$ & & & & & & & 1.01 & {$[0.54]$} & 3.00 & {$[1.48]$} & 1.83 & {$[0.89]$} \\
\hline Controls & & No & & Yes & & Yes & & No & & Yes & & Yes \\
\hline \multicolumn{13}{|l|}{ Fixed effects: } \\
\hline Country & & Yes & & Yes & & Yes & & No & & No & & No \\
\hline Year & & No & & No & & Yes & & No & & No & & Yes \\
\hline $\mathrm{N}$ & & 407 & & 407 & & 407 & & 388 & & 388 & & 388 \\
\hline $\mathrm{R}^{2}$ & & 0.08 & & 0.16 & & 0.23 & & 0.09 & & 0.13 & & 0.20 \\
\hline
\end{tabular}


Table 6. FDI and Stock Market Valuations: Alternative Definitions of Capital Account Closedness. Regressions of FDI into the US on the source country market-to-book ratio, the US market-to-book ratio, their interactions with a capital account openness index, and controls. The FDI data are from the BEA. All variables are summarized in Table 1 . We decompose the source country market-to-book ratio into a non-fundamental or mispricing component (Fitted $\left.\mathrm{M} / \mathrm{B}_{i t}\right)$ and a fundamental component (Residual $\mathrm{M} / \mathrm{B}_{\text {it }}$ ). The decomposition is based on a first stage regression of market-to-book on future returns: Fitted $\mathrm{M} / \mathrm{B}_{\text {it }}=1.82-$ $0.72 \mathrm{R}_{i t+1}(\mathrm{~N}=426$, t-stat=5.07). Market-to-book or its components are then interacted with alternative versions of the Brune et al. (2001) measure of capital account closedness for the second stage regression. The Brune et al. measure includes restrictions on five types of activities: invisible transactions, capital and money market transactions, credit market operations, FDI, and commercial banking transactions. The first four are divided into ingoing and outgoing restrictions. We consider measures that exclude the FDI components of the index; that are based only on capital market restrictions; and that are based only on outgoing FDI restrictions. Each measure is separately standardized to have zero mean and unit variance. Heteroskedasticity robust t-statistics are in braces.

\begin{tabular}{|c|c|c|c|c|c|c|c|c|c|c|c|c|}
\hline & \multicolumn{12}{|c|}{ FDI into the US (FDI $\left.{ }_{i U S t}\right)$} \\
\hline & \multicolumn{6}{|c|}{$\mathrm{M} / \mathrm{B}$} & \multicolumn{6}{|c|}{ M/B decomposition } \\
\hline & \multicolumn{2}{|c|}{ Excluding FDI } & \multicolumn{2}{|c|}{$\begin{array}{c}\text { Outgoing FDI } \\
\text { closedness }\end{array}$} & \multicolumn{2}{|c|}{$\begin{array}{c}\text { Capital market } \\
\text { closedness }\end{array}$} & \multicolumn{2}{|c|}{ Excluding FDI } & \multicolumn{2}{|c|}{$\begin{array}{c}\text { Outgoing FDI } \\
\text { closedness }\end{array}$} & \multicolumn{2}{|c|}{$\begin{array}{c}\text { Capital market } \\
\text { closedness }\end{array}$} \\
\hline & Coef & t-stat & coef & t-stat & coef & t-stat & coef & t-stat & coef & t-stat & coef & t-stat \\
\hline $\mathrm{M} / \mathrm{B}_{i t}$ & 9.41 & [3.69] & 7.68 & [3.79] & 7.77 & [3.72] & & & & & & \\
\hline $\mathrm{M} / \mathrm{B}_{i t} \cdot \mathrm{CAC}_{i t}$ & 3.57 & [1.32] & 0.75 & {$[0.49]$} & 3.53 & {$[1.78]$} & & & & & & \\
\hline Fitted $\mathrm{M} / \mathrm{B}_{i t}$ & & & & & & & 16.03 & [1.88] & 22.20 & {$[2.85]$} & 16.61 & [2.00] \\
\hline Fitted $\mathrm{M} / \mathrm{B}_{i t} \cdot \mathrm{CAC}_{i t}$ & & & & & & & 22.89 & [3.52] & 1.13 & {$[0.21]$} & 25.92 & [3.20] \\
\hline Residual M/Bit & & & & & & & 9.60 & [3.36] & 8.08 & [2.93] & 8.38 & [3.14] \\
\hline Residual $\mathrm{M} / \mathrm{B}_{i t} \cdot \mathrm{CAC}_{i t}$ & & & & & & & 1.97 & [0.93] & 1.19 & {$[0.76]$} & 2.15 & [1.19] \\
\hline Controls & & Yes & & Yes & & Yes & & Yes & & Yes & & Yes \\
\hline \multicolumn{13}{|l|}{ Fixed effects: } \\
\hline Country & & Yes & & Yes & & Yes & & No & & No & & No \\
\hline Year & & Yes & & Yes & & Yes & & Yes & & Yes & & Yes \\
\hline $\mathrm{N}$ & & 407 & & 407 & & 407 & & 388 & & 388 & & 388 \\
\hline $\mathrm{R}^{2}$ & & 0.23 & & 0.23 & & 0.24 & & 0.21 & & 0.18 & & 0.21 \\
\hline
\end{tabular}

